\title{
Cushing syndrome due to an adrenal phaeochromocytoma
}

\section{ADCJ Gunasekara', AP Premawardhena ${ }^{2}$, HANS Hettiarachchi ${ }^{3}$, BG Ratnasena ${ }^{4}$ and HJ de Silva ${ }^{5}$}

(Index words: Cushing syndrome, phaeochromocytoma)

\section{Introduction}

Adrenal phaeochromocytoma is a rare cause of Cushing syndrome [1-3]. We describe a 16-year old girl with Cushing syndrome with a right suprarenal mass on CT scanning which was histologically confirmed.

\section{Case report}

A 16-year old schoolgirl with rapid onset of weight gain had central obesity, purplish streaky lesions in the upper thighs, abdomen and buttocks, hair loss and acne. She had amenorrhoea throughout the period and also noticed progressive difficulty in rising from the squatting position. On examination her BMI was 22.8. She was plethoric, had a moon face, a buffalo hump, frontal hair loss (Figure 1) and central obesity with purple striae over the abdomen, thighs and calves. She had a fine tremor, some hyperpigmented patches in both hands and grade 4 proximal muscle weakness without wasting, with normal tendon reflexes. Her blood pressure was $160 / 110 \mathrm{mmHg}$ without a postural drop. There was no hirsutism or signs of virilisation.

The low dose dexamethasone suppression test was positive [basal cortisol level was over $2000 \mathrm{nmol} / \mathrm{L}$ and unchanged after 48 hours of dexamethasone]. After high

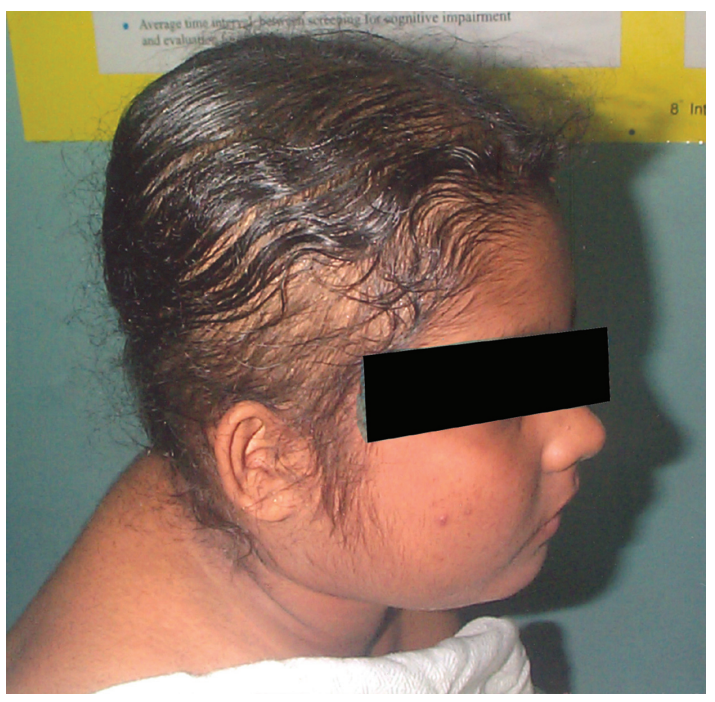

Figure 1. Facial features of Cushing syndrome in the patient. dose dexamethasone the serum cortisol level was still over $2000 \mathrm{nmol} / \mathrm{L}$. Ultrasound scan of the abdomen showed a round solid mass with mixed echogenicity $(8 \mathrm{~cm} \times 8.9 \mathrm{~cm})$ in the right suprarenal area, and CT scan confirmed a mixed density right suprarenal mass (Figure 2). Both scans suggested a phaeochromocytoma, and not a cortical tumour. Urinary VMA, metanephrines and plasma ACTH were not performed. She underwent an uneventful right adrenalectomy and the histology of the tumour (Figure 3) showed a phaeochromocytoma

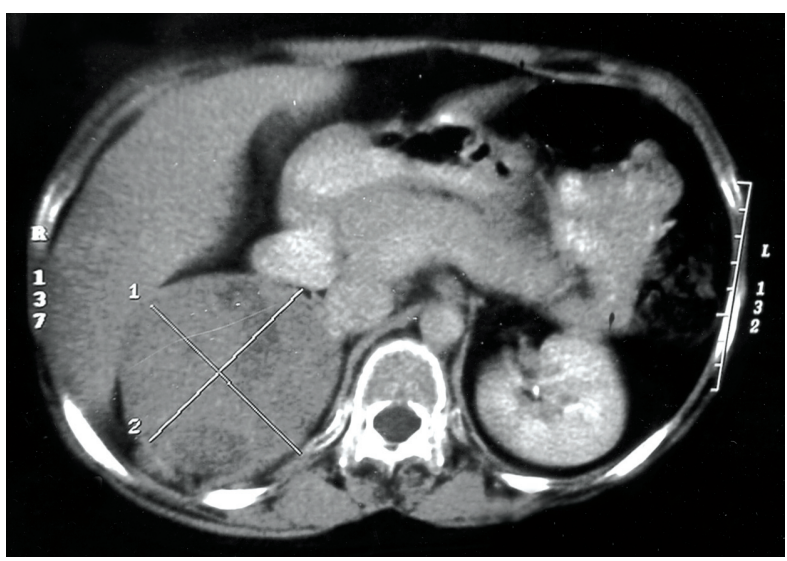

Figure 2. CT scan of the abdomen showing the adrenal medullary tumor.

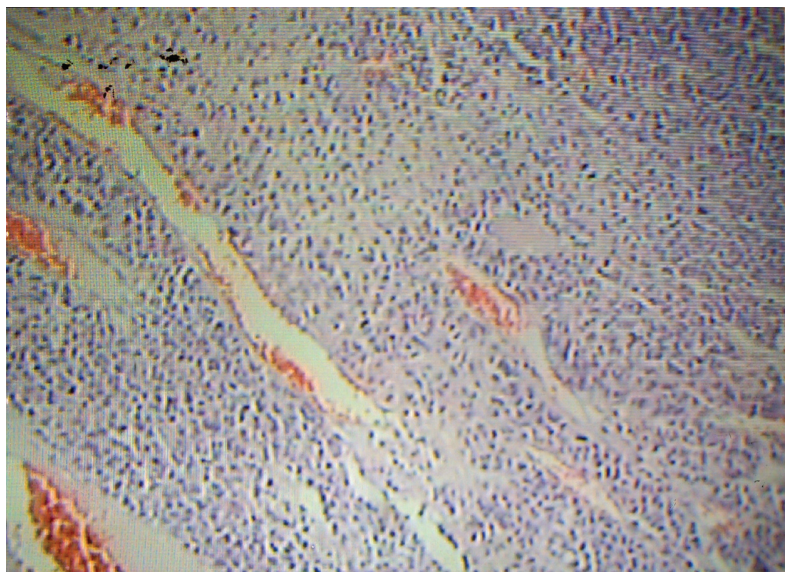

Figure 3. A histological section of the adrenal medullary tumour showing poor prognostic features.

\footnotetext{
${ }^{1,3}$ Registrar and Senior Registrar, Professorial Unit (Medicine), and ${ }^{4}$ Surgeon, North Colombo Teaching Hospital, ${ }^{2}$ Senior Lecturer and ${ }^{5}$ Professor in Medicine, Faculty of Medicine, University of Kelaniya, Sri Lanka.

Correspondence: APP, e-mail: <premawa@hotmail.com> and <anuja@mfac.kln.ac.lk> (Competing interests: none declared). Received 10 December 2005 and accepted subject to minor amendments 8 April 2006.
} 
with poor prognostic features with pleomorphism, tumour necrosis high mitosis. Post-operatively she recovered well and was discharged on replacement steroids, subsequently tailed off.

\section{Comment}

Adrenal medullary phaeochromocytomas could rarely cause Cushing syndrome by causing ectopic ACTH hormone secretion [4,5]. Ignoring this possibility could lead to severe peri-operative complications when resection of the tumor is envisaged.

\section{Acknowledgements}

Dr Janaki Fernando, Pathologist, North Colombo (Teaching) Hospital, Dr Deepika Gunawardhena and RAN Samarasinghe are thanked for their assistance.

\section{References}

1. White A, Ray DW, Talbot A, Abraham P, Thody AJ, et al. Cushing syndrome due to phaeochromocytoma secreting the precursors of adrenocorticotropine. The Journal of Clinical Endocrinology and Metabolism 2000; 85: 4771-5.

2. Venihaki M, Ain K, Dermitazaki E, Gravanis A, Morgioris AN. KAT45 noradrnergic human phaeochromocytoma cell-line producing corticotropine releasing hormone. Endocrinology 1998; 139: 2713-2.

3. Sweeney AT, Blake MA, Chelby J. Phaeochromocytoma. eMedicine. January 14, 2002.

4. Eisonhofen G, Bornstein SR, Brouwers FM, Cheung NV, Dahia PL, et al. Malignant phaeochromocytoma. Endocrine Related Cancer 2004; 11: 423-6.

5. Terzolo M, Ali A, Bollito F, Reimondo G, Paccolti G. Cyclical Cushing syndrome due to ectopic ACTH secretion by an adrenal phaeochromocytoma. Journal of Endocrinological Investigation 1994; 17: 864-4. 